\title{
Proteomic analysis of PBMCs: characterization of potential HIV-associated proteins
}

\author{
Lijun Zhang ${ }^{1 *}{ }^{+}, X_{i a o f a n g} \mathrm{Jia}^{1+}{ }^{+}$, Xiaojun Zhang $^{2 \dagger}$, Jianjun Sun ${ }^{1}$, Xia Peng ${ }^{1}$, Tangkai Qi ${ }^{1}$, Fang Ma ${ }^{1}$, Lin Yin ${ }^{1}$, \\ Yamin Yao ${ }^{1}$, Chao Qiu ${ }^{3}$, Hongzhou Lư ${ }^{1 *}$
}

\begin{abstract}
Background: The human immunodeficiency virus type 1 (HIV-1) pandemic has continued unabated for nearly 30 years. To better understand the influence of virus on host cells, we performed the differential proteome research of peripheral blood mononuclear cells (PBMCs) from HIV-positive patients and healthy controls.

Results: 26 protein spots with more than 1.5-fold difference were detected in two dimensional electrophoresis (2DE) gels. 12 unique up-regulated and one down-regulated proteins were identified in HIV-positive patients compared with healthy donors. The mRNA expression of 10 genes was analyzed by real time RT-PCR. It shows that the mRNA expression of talin-1, vinculin and coronin-1C were up-regulated in HIV positive patients and consistent with protein expression. Western blotting analysis confirmed the induction of fragments of vinculin, talin-1 and filamin-A in pooled and most part of individual HIV-positive clinical samples. Bioinformatic analysis showed that a wide host protein network was disrupted in HIV-positive patients.
\end{abstract}

Conclusions: Together, this work provided useful information to facilitate further investigation of the underlying mechanism of HIV and host cell protein interactions, and discovered novel potential biomarkers such as fragment of vinculin, filamin-A and talin-1 for anti-HIV research.

\section{Background}

The human immunodeficiency virus type 1 (HIV-1) pandemic has continued unabated for nearly 30 years. Globally, there are estimated 33.4 million living individuals in 2008 according to AIDS epidemic update 2009 by the World Health Organization (WHO) http://www. unaids.org/en/KnowledgeCentre/HIVData/EpiUpdate/ EpiUpdArchive/2009/default.asp. Current therapies direct against viral proteins. Highly active anti-retroviral therapy has been problematic because of long-term toxicity, inhibitor resistance, and the inability to target persistent reservoirs[1,2]. Thus, there is a need for the comprehensive elucidation of HIV-1-mediated effects on host cellular protein networks and unique protein targets for the design of therapeutic drugs.

Over the past few decades, HIV-mediated effects on host cells have typically involved the study of one gene or one protein at a time, to elucidate their functions in

\footnotetext{
* Correspondence: zhanglijun1221@163.com; luhongzhou@yahoo.com † Contributed equally

${ }^{1}$ Shanghai Public Health Clinical Center affiliated to Fudan University, Shanghai, 201508, PR China
}

lymphocyte or monocyte biology, signaling pathways or immune system [3-5]. However, the method for one gene or one protein is too slow to elucidate HIV mediated effects on host cells.

The advent of proteomics has expanded the focus on cellular function from examination of gene structure and function to the analysis of their encoded proteins. Analyzing encoded proteins is an important advance because proteins are ultimately responsible for controlling most aspects of cellular function, can be regulated by post-translation modification (PTM), and can not be ascertained from simple analysis of gene transcription or translation. Proteomics has been widely used in the study of pathogenesis, etiology and pathology of infectious disorders such as HIV/HIV-positive, tuberculosis, malaria, measles, and hepatitis as reviewed by LIST EO. et al [6] Through proteome research, researchers found some new possible biomarkers for HIV-associated cognitive neurological disorders (HAND) diagnosis, such as $\mathrm{Cu} / \mathrm{Zn}$ superoxide dismutase ( $\mathrm{Cu} / \mathrm{Zn}$ SOD), new treating targets such as PDI-A3 which were up-regulated after zidovudine (AZT) treatment [7]. Furthermore, great 
progress was obtained in virus-host cell interaction. For example, HIV replication enhances the production of free fatty acids, low density lipoproteins and many key proteins involved in lipid metabolism[8]. Viral infection down-regulates matrix metalloproteinase 9 (MMP 9) secretion[9]. These observations show the potential power of proteomics for the analysis of cellular proteins involved in diseases.

Peripheral blood mononuclear cells (PBMCs) have been recognized as key players in the innate and adaptive immune responses for their ability to recognize molecular patterns that are typical of microorganisms and by their molecular and functional adaptation to invade pathogens $[10,11]$. Currently, PBMCs are widely used in research and clinical practice, especially in HIVpositive patients [12]. According to previous reports [13-15] carried in PBMC, human immunodeficiency virus type 1 (HIV-1) infections are associated with functional defects in CD4 T cells, marked by unresponsiveness to $\mathrm{T}$-cell signaling, as well as an increased propensity to mitochondrial membrane potential and apoptosis. Several researches [16-18] have shown that HIV-1 induced a lot of changes in host cellular proteins, including caspase 9 and caspase 3-dependent apoptosis, intracellular transport, oxidative stress, etc. However, our knowledge is limited to understand such a complicated virus-host interaction.

In this study, we analyzed HIV-1-mediated effects on host cellular networks through PBMCs proteomics. PBMCs were isolated from EDTA-anticoagulated blood collected from HIV-positive patients or healthy donors by ficoll density centrifugation. Proteins of PBMCs were extracted and separated by two-dimensional gel electrophoresis (2DE). The differentially expressed proteins between HIV-positive and healthy donors were identified by ESI-Ion trap and MALDI-TOF/TOF mass spectrometry. The mRNA expression of 10 genes was analyzed by real time RT-PCR. The expression of talin1, filamin-A, GNB1 and vinculin was further validated by western blotting analysis. Presented data provided novel insights into HIV and host interaction. Potential new biomarkers were found, including fragment of vinculin for anti-HIV research.

\section{Methods}

\section{Human subjects}

$43 \mathrm{HIV}$-positive patients and 42 healthy donors were enrolled in this study (Table 1), including 9, 22 and 12 from patients and 11, 20 and 11 from healthy donors for two dimensional electrophoresis (2DE), PCR and western blotting (WB), respectively. Patients with HIV infection who did not receive antiviral treatment or immunotherapy in the past 6 months and were followed up at Shanghai Public Health Clinical Center were recruited. All patients met the diagnostic criteria of HIV-positive with CD4 $<350 / \mu \mathrm{L}$, and negative for hepatitis $\mathrm{C}$ virus (HCV) and hepatitis B virus (HBV). Blood samples of healthy donors were the remaining samples after medical tests ordered by the physicians at Shanghai Public Health Clinical Center, and were tested negative for human HIV, HBV and HCV. The study protocol was approved by the local Ethics Committee, and all patients were given a written informed consent.

\section{PBMCs separation and detection}

Peripheral whole blood $(5 \mathrm{~mL})$ was collected into an EDTA-anticoagulated tube. PBMCs were isolated via density gradient centrifugation using Ficoll-Paque ${ }^{\mathrm{TM}}$ Plus (Amersham Pharmacia Biotech) according to the manufacturer's instructions. After ficoll density gradient centrifugation, the upper suspension was removed softly, and the white PBMCS were absorbed and washed twice with PBS by low-speed centrifugations (200 g, $10 \mathrm{~min}$ ). 90 percent of collected PBMC pellets were frozen at $-80^{\circ} \mathrm{C}$ within $4 \mathrm{~h}$ from blood collection for proteomic research. The rest was diluted to $200 \mu \mathrm{L}$ PBS and used for platelet count through analyzed by Blood Cell Analysis Instrument (Cell-Dyn3200, Abbott, Washington, 98057 USA) using standard clinical detection method which meets US Clinical Laboratory Improvement Amendments of 1988 guidelines for AHA performance standard [19].

\section{DE and image analysis}

2DE was performed with the IPGphor system (GE (formerly Amersham Bioscience), USA) and PROTEAN II system (Bio-Rad, Hercules, California), as previously described [20]. Briefly, IPG dry strips (pH 3-10 NL (180 $\times 30 \times 0.5 \mathrm{~mm}$ )) was used. Isoelectricfocusing (IEF) was conduced automatically to a total of $52.1 \mathrm{KVh}$. After equilibration, proteins were separated in $11.5 \%$ separation gels with $25 \mathrm{~mA} /$ gel constant current. The separation gels were made by us according to the standard protocol described by Gorg et al[21]. Three couples of 2 -D gels with protein load of $250 \mu \mathrm{g}$ were stained by silver nitrate for image analysis. Another couple of 2-D gels with protein load of $1,000 \mu \mathrm{g}$ were stained with Coomassie brilliant blue (CBB) for protein identification.

For image analysis, Imagemaster 2D software (GE Company, USA) was used according to the manufacturer. Briefly, the individual spot volumes were normalized by dividing their optical density (OD) values by the total OD values of all the spots on the gel to remove the artificial factors. The three parallel gels from HIVpositive or healthy donors were divided into a group respectively, and the matched spots in the three parallel gels were averaged respectively. The threshold defined as the significant change in relative spot volume was at 
Table 1 Characteristics of patients with HIV and healthy donors

\begin{tabular}{lllllll}
\hline Parameter & & \multicolumn{2}{c}{ Patients } & & \multicolumn{2}{c}{ Healthy donors } \\
& 2DE & PCR & WB & 2DE & PCR & WB \\
\hline Number & 9 & 22 & 12 & 11 & 20 & 11 \\
Age & $40.5 \pm 10.3$ & $42.1 \pm 12.0$ & $44.0 \pm 9.4$ & $38.5 \pm 11.6$ & $41.3 \pm 12.3$ & $41.0 \pm 10.1$ \\
Female & 2 & 3 & 4 & 2 & 4 & No \\
HIV & & Yes & & & No \\
HBV & & No & & No \\
HCV & & No & & & / \\
CD4 & & & & & \\
\hline
\end{tabular}

Selection criteria

1. 18 to 60 years old;

2. Consistent with the diagnostic criteria of HIV infection according to the guidelines of prevention and treatment for HIV-positive in China;

a) The clinical history of HIV-positive;

b) $\mathrm{CD} 4<350 / \mu \mathrm{L}$;

3. Have not received antiviral treatment or immunotherapy;

4. Negative for other viral infections, including HCV and HBV according to antibody test.

least 1.5 -fold comparing the average gels of the HIVpositive with that of healthy donors.

\section{Trypsin Digestion and Protein identification}

The protein spots were manually excised, and in-gel digested as described $[20,22]$. The digested peptides were analyzed by esquire high capacity ion trap (HCT) mass spectrometer (Bruker, Germany) and MALDITOF/TOF (Bruker, Germany). For HCT analysis, the tryptic peptide mixtures were injected onto a $\mathrm{C} 18 \mu$-precolumn $\left(300 \mu \mathrm{m}\right.$ id $\times 5 \mathrm{~mm}, 5 \mu \mathrm{m}$, PepMap $\left.{ }^{\mathrm{rm}}\right)$ (LC Packings, Amsterdam, the Netherlands) with a flow rate of $20 \mu \mathrm{L} / \mathrm{min}$ in Ultimate 3000 (Dionex Corporation, USA). After desalted by precolumn, the peptides were eluted to a C-18 reversed-phase nanocolumn $(75 \mu \mathrm{m}$ id $\times 15 \mathrm{~cm}$ length, $3 \mu \mathrm{m}$, PepMap ${ }^{\mathrm{Tm}}$ ) (LC Packings) using a $3-50 \%$ continuous acetonitrile gradient at $300 \mathrm{~nL} / \mathrm{min}$. The eluted peptides from the reversed-phase nanocolumn were on line injected to a PicoTip emitter nanospray needle (New Objective, Woburn, MA, USA) for real-time ionization and peptide fragmentation on HCT mass spectrometer.

For MALDI-TOF/TOF analysis, the tryptic peptide mixtures were loaded onto a 384 AnchorChip target (Bruker Daltonik, Bremen, Germany) and analyzed by mass spectrometry according to our published papers $[20,22,23]$.

The MS/MS data was input to MASCOT 2.0 program (MatrixScience, Boston, MA, USA) to search against SwissProt 54.8 identification. Search parameters were set as follows: enzyme, trypsin; allowance for up to one missed cleavage peptide; mass tolerance, 1.2 Da for HCT and $50 \mathrm{ppm}$ for MALDI-TOF/TOF, and MS/MS mass tolerance, $0.6 \mathrm{Da}$; fixed modification parameter, carbamoylmethylation (C); variable modification parameters, oxidation (at Met); auto hits allowed (only significant hits were report); results format as peptide summary report. Proteins were identified on the basis of peptides whose ions scores exceeded the threshold ( $\mathrm{p}<$ 0.05 ), which indicates identification at the $95 \%$ confidence level for these matched peptides. For HCT data, proteins identified by more than 4 peptides were accepted and each peptide was manually inspected. Of which, there must be a peptide with four or more continue y-or b-series ions (e.g., y4, y5, y6, y7). For MALDI-TOF/TOF analysis, only proteins with scores over 62 were accepted.

\section{Data analysis and bioinformatics}

The function of the identified proteins was elucidated by SWISS-PROT database http://www.expasy.org and the interaction between the differentially expressed proteins and HIV proteins were checked by HIV interaction database http://www.ncbi.nlm.nih.gov/RefSeq/HIVInteractions. A protein-protein interaction network was drawn by STRING $8.0 \mathrm{http}: / /$ string.embl.de/ using proteins identified in this work and data from SWISS-PROT function annotation as input. Cytoscape software was used to integrate human proteins with HIV proteins to draw a protein-protein interaction of HIV and host cell proteins.

\section{RNA extraction and quantitative real-time RT-PCR}

Total RNA from PBMCs was extracted using Trizol reagent (Invitrogen Life Technologies) following the manufacturer's instructions and the described previously[5]. Briefly, real-time PCR was performed in the iCycler iQ Multicolor Real-Time PCR Detection System (Bio-Rad Laboratories) using the SYBR Green (ToYoBo). $2 \mu \mathrm{l}$ cDNA templates was used for each PCR with $0.7 \mu \mathrm{l} 10$ $\mathrm{nM}$ sense and antisense primers (Table 2) in a total volume of $25 \mu \mathrm{l}$. The thermal cycling conditions comprised $3 \mathrm{~min}$ at $95^{\circ} \mathrm{C}$, followed by 40 cycles at $95^{\circ} \mathrm{C}$ for $5 \mathrm{~s}$, 
Table 2 Quantitative analysis results of mRNA expression of 10 differentially expressed proteins in PBMCs from HIVpositive patients and healthy donors.

\begin{tabular}{|c|c|c|c|c|c|c|}
\hline gene name & strand & primer & Aaymp. Sig.(2-tailed) & $\begin{array}{l}\text { Number } \\
\text { (HIV/Normal) }\end{array}$ & $\begin{array}{l}\text { Mean peak } \\
\text { (HIV/Normal) }\end{array}$ & $\begin{array}{l}\text { Expression of proteins } \\
\text { in HIV }\end{array}$ \\
\hline KPYM & $\begin{array}{l}\text { sense } \\
\text { antisense }\end{array}$ & $\begin{array}{l}\text { ctatcctctggaggctgtgc } \\
\text { ccagacttggtgaggacgat }\end{array}$ & 0.029 & $10 / 10$ & 0.6 & $\uparrow 11.9$ \\
\hline TLN1 & $\begin{array}{l}\text { sense } \\
\text { antisense }\end{array}$ & $\begin{array}{l}\text { tctcccaaaatgccaagaac } \\
\text { ctccactagcccttgctgtc }\end{array}$ & 0.022 & $20 / 22$ & 1.5 & $\uparrow 4.1$ \\
\hline CAP1 & $\begin{array}{l}\text { sense } \\
\text { antisense }\end{array}$ & $\begin{array}{l}\text { gtgtcaacagccagcagaaa } \\
\text { gcggcatcattcatttcttt }\end{array}$ & 0.004 & $10 / 10$ & 0.8 & Only \\
\hline ENOA & $\begin{array}{l}\text { sense } \\
\text { antisense }\end{array}$ & $\begin{array}{l}\text { gagctccgggacaatgataa } \\
\text { tgttccatccatctcgatca }\end{array}$ & 0.631 & $10 / 10$ & 1.1 & Only \\
\hline EHD3 & $\begin{array}{l}\text { sense } \\
\text { antisense }\end{array}$ & $\begin{array}{l}\text { ctaaccctgtgctggagagc } \\
\text { gtcagctttgttcagcacca }\end{array}$ & 0.009 & $10 / 10$ & 0.8 & Only \\
\hline COR1C & $\begin{array}{l}\text { sense } \\
\text { antisense }\end{array}$ & $\begin{array}{l}\text { gcagaagagtggttcgaagg } \\
\text { tgatcaggtcgcacttcttg }\end{array}$ & 0.047 & $20 / 22$ & 1.4 & $\uparrow 2.0$ \\
\hline ST1A3 & $\begin{array}{l}\text { sense } \\
\text { antisense }\end{array}$ & $\begin{array}{l}\text { catgaaggagaaccccaaaa } \\
\text { tgaaggtggtcttccagtcc }\end{array}$ & 0.739 & $10 / 10$ & 1.1 & $\uparrow 1.8$ \\
\hline FLNA & $\begin{array}{l}\text { sense } \\
\text { antisense }\end{array}$ & $\begin{array}{l}\text { aagtgaccgccaataacgac } \\
\text { ggcgtcaccctgtgacttat }\end{array}$ & 0.393 & $10 / 10$ & 0.8 & $\uparrow 1.7$ \\
\hline VINC & $\begin{array}{l}\text { sense } \\
\text { antisense }\end{array}$ & $\begin{array}{l}\text { gccaagcagtgcacagataa } \\
\text { tctttctaacccagcgcagt }\end{array}$ & 0.007 & $20 / 22$ & 1.6 & $\uparrow 14.1$ \\
\hline GNB1 & $\begin{array}{l}\text { sense } \\
\text { antisense }\end{array}$ & $\begin{array}{l}\text { cttgtgatgcttcagccaaa } \\
\text { tcagcacgaaggtcaaacag }\end{array}$ & 0.078 & $20 / 22$ & 1.4 & $\downarrow 1.5$ \\
\hline
\end{tabular}

Isolated PBMCs from HIV-positive and healthy donors were treated with Trizol regent and RNA was extracted according to the manufacturer's instructions. The primers were obtained through primer 3.0 software analysis. The data were statistic analyzed through Mann-Whitney test.

$60^{\circ} \mathrm{C}$ for $20 \mathrm{~s}$, and $72^{\circ} \mathrm{C}$ for $20 \mathrm{~s}$. All of the reactions were performed in duplicate. The threshold cycle of each PCR was converted to a DNA equivalent by reading standard curves generated by amplifying dilutions of a linearized plasmid containing the 188 bp GAPDH cDNA. The relative quantity of the target mRNA was normalized to the level of the internal control GAPDH mRNA level.

\section{Western blotting and densitometry analysis}

Fifty micrograms of total protein extracts from pooled and individual samples (12 HIV-positive patients and 8 healthy donors for GNB1, talin-1, vinculin and filamin A) were separated by electrophoresis in SDS-10\% polyacrylamide gel and transferred to PVDF membrane (Millipore). After blocking in 10\% defatted milk for $2 \mathrm{~h}$, blots were incubated overnight at $4{ }^{\circ} \mathrm{C}$ with specific primary antibodies (GNB1, 1:2000; talin-1, 1:1000; filamin A, 1:5000, viculin, 1:2000). After three washes with TBS-Tween-20, blots were incubated for $1 \mathrm{~h}$ at $20^{\circ} \mathrm{C}$ with secondary antibody. After further washes, the immune complexes were revealed by enhanced chemiluminescence and detected by X-rays. Each experiment was repeated for three times.

\section{Statistical Analysis}

For all studies, experiments were repeated at least twice. For quantitative data, means and P value were computed. For platelet count and real-time RT-PCR, Mann-
Whitney Test was used. For protein spot density in 2DE, a Two-sample $t$ Test software analysis packed in Imagemaster software was used.

\section{Results \\ PBMC analysis}

After Ficoll centrifugation, the white blood cell ring fraction (about $2 * 10^{6}$ PBMCs $/ 5 \mathrm{~mL}$ whole blood) was collected and used for PBMC quality analysis or proteomic research. To check the contamination of platelets, the blood cell analysis was carried. As shown in Additional file 1, table S1, $25.2 \pm 27.8$ (average \pm std, $\mathrm{n}=13$ ) and $24.1 \pm 24.4 \mathrm{e}^{*} 10^{9} / \mathrm{L}$ (average $\pm \mathrm{std}, \mathrm{n}=11$ ) platelets were detected in the PBMCs from 13 healthy controls and 11 HIV-positive patients respectively. The platelets were reduced for 4 to 12 -fold compared with normal reference (100 to 300$)^{*} 10^{9} / \mathrm{L}$. No statistic difference was found between HIV-positive patients and healthy controls through Mann-Whitney Test statistic analysis $(\mathrm{P}=0.34)$.

\section{2-DE and the analysis of gel images}

Proteins can be well separated through pH3-10 NL gel stripe in the first dimension and $11.5 \%$ separation gel in the second dimension. $1275 \pm 242$ and $1091 \pm 172$ protein spots were detected in silver-stained 2DE gels of the HIVpositive and the controls through ImageMaster software analysis and confirmed by manually checking. A typical 
CBB-stained 2-DE proteome spot pattern of PBMCs from HIV-positive patients and healthy controls was shown in Figure 1. 26 protein spots with 1.5 or more fold difference were detected. The partially magnified images of five protein spots including talin-1(TLN1) (spot 2), filamin-A (FLNA) (spot 9), etc. were shown in Figure 2A.

\section{Protein identification}

As shown in Table 3 and Figure 1, 20 differentially expressed spots were successfully identified which corresponding to 13 non-redundant proteins identified by HCT with more than four peptides, four of which were simultaneously identified by MALDI-TOF/TOF (Additional file 2, Table S2). These four proteins identified by both HCT and MALDI-TOF/TOF were talin-1, filamin$A$, vinculin and $\mathrm{EH}$ domain-containing protein 3 with increased expression in HIV-positive patients compared with healthy controls. According to annotations from UniProt knowledgebase (Swiss-Prot/TrEMBL) and Gene Ontology Database, the identified proteins were involved in various cellular functions including binding (7 proteins), enzyme (4 proteins), signal transduction ( 2 proteins) and immune response (one protein). In particular, most of the differential proteins (58\%) were membrane proteins such as talin-1, filamin-A, etc. Furthermore, many different spots were identified to be the products of the same gene such as actin(ACTB), adenylyl cyclaseassociated protein 1 (CAP1) and alpha-enolase (ENOA).

\section{Protein-protein interaction}

As we know, HIV infection is depending on the interaction between HIV proteins and host cell proteins. In this work, bioinformatics analysis was performed to elucidate the network between the identified differential proteins and HIV function proteins. As shown in Figure 3, a wide protein-protein interaction network was affected in HIV/ AIDS patients. For example, the host protein interaction net such as VCL - TLN1 - actin, cytoplasmic 2(ACTG1) - FLNA was found to interact with nef and pol (HIV function proteins), and be substantially up-regulated in HIV/AIDS patients. The similar result was observed in ENOA-(L-lactate dehydrogenase B chain) LDHB - pyruvate kinase isozymes M1/M2 (PK3) network which interacting with rev, gp41 and gp120 (HIV function proteins). The related network-protein information is listed in Additional file 3, Table S3.

\section{Transcriptional profiles of differentially expressed proteins}

In order to make sure whether the protein expression change happens at the transcriptional or translational level, the transcriptional alterations of 10 selected genes in PBMCs from HIV-infected patients (10 or 20) and healthy donors (10 or 22) were measured by quantitative real-time RT-PCR using the mRNA transcript of GAPDH as a control housekeeping gene. As shown in Table 2 and Figure 4, VINC, TLN1, CAP1, pyruvate kinase isozymes M1/M2

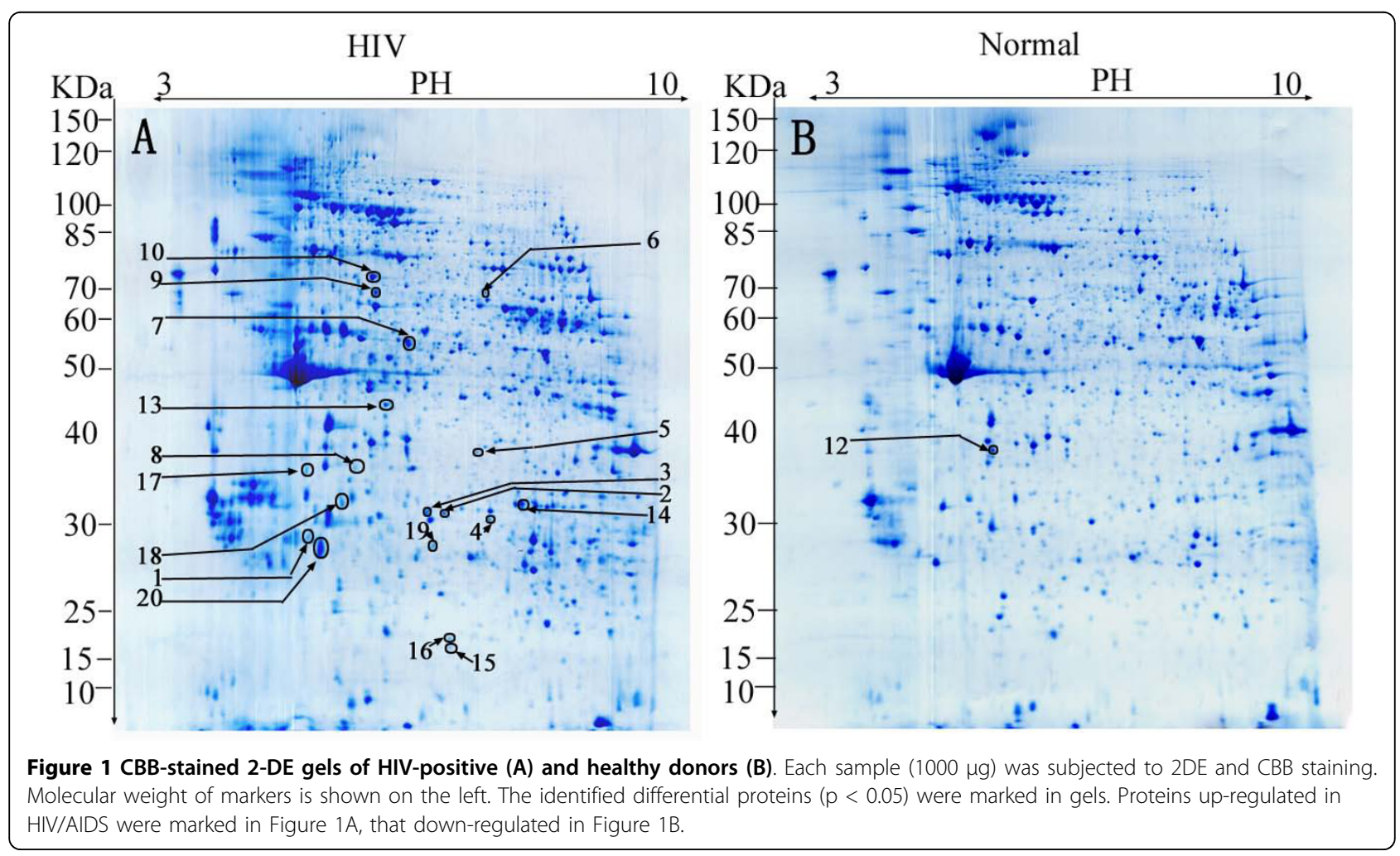




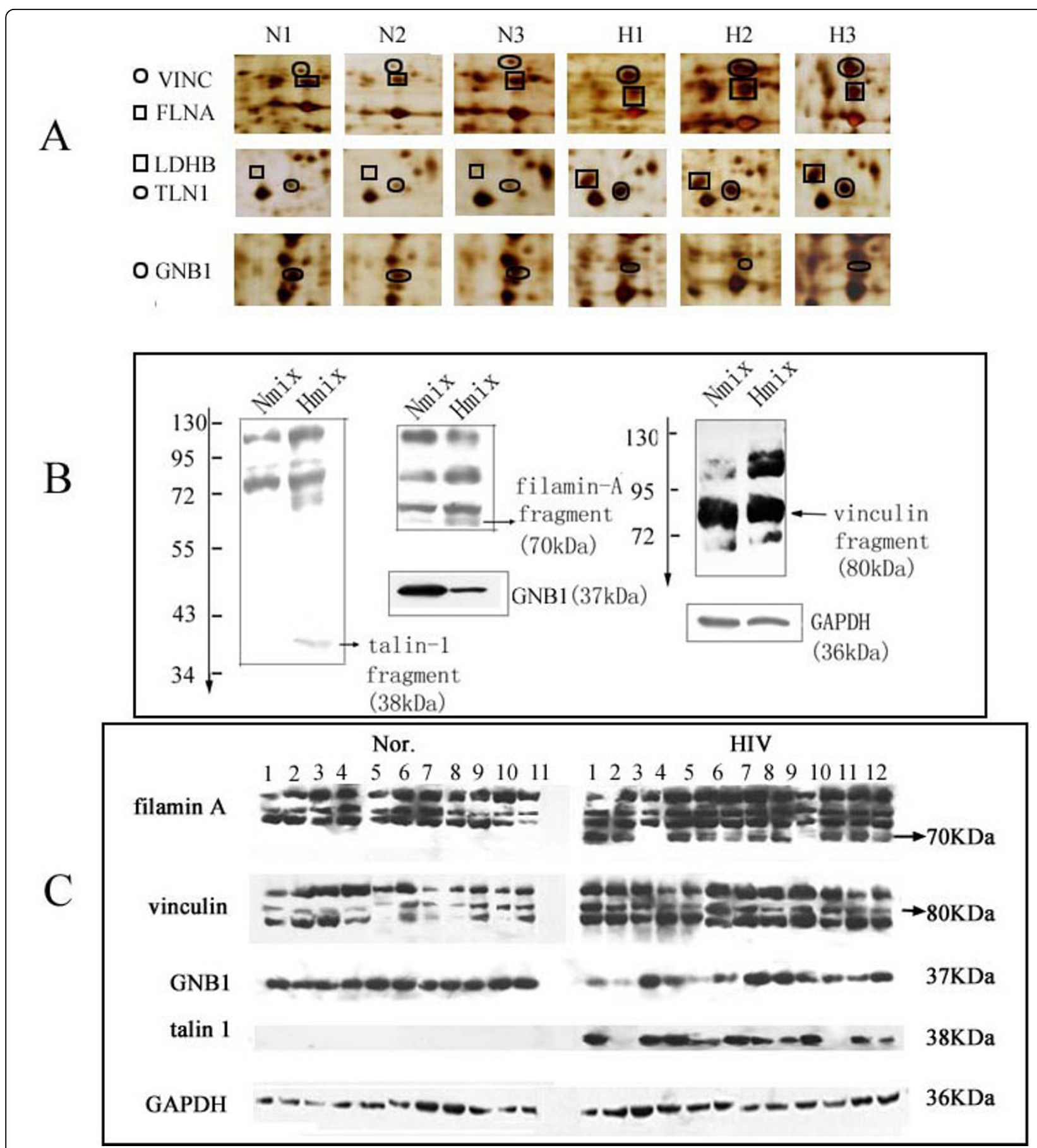

Figure 2 Western blotting verification of part of the differential proteins. A. Partially magnified images of five protein spots in $2 \mathrm{D}$ gels. B. Western blotting confirmation of talin-1, filamin-A, vinculin and GNB1 in pooled samples. C. Western blotting of GNB1, talin-1, vinculin and filamin-A in 23 individuals (12 from patients and 11 from healthy controls). GAPDH was used as the internal control.

(KPYM), EH domain-containing protein 3 (EHD3) and coronin-1C (COR1C) were found to be statistically different between HIV-positive patient and healthy donors. The expression of VINC, TLN1 and COR1C was up-regulated by $1.5,1.6$ and 1.4 fold, respectively, which was consistent with the results from 2DE-MS. In contrast, KPYM has the contrast result with 2DE-MS, down-regulated by 1.7-fold. CAP1 and EHD3 were changed a little with about 0.8 to 1.2- fold differences respectively. FLNA, GNB1, alpha-enolase (ENOA) and sulfotransferase 1A3/1A4 (ST1A3), were found to be no difference between HIV-positive and healthy donors. 
Table 3 List of the differentially expressed protein spots in 2DE of HIV-positive and healthy donors identified by ESIMS or both ESI-MS and MALDI-TOF/TOF.

\begin{tabular}{|c|c|c|c|c|c|c|c|c|c|}
\hline spot $^{a}$ & Accession NO. & Protein description & $\mathrm{MW}^{\mathrm{c}}$ & pl & Score $^{d}$ & Cov. $^{e}$ & $\begin{array}{l}\text { Abundance } \\
\text { HIV/NOR }\end{array}$ & Function $^{f}$ & Location $^{\mathrm{g}}$ \\
\hline 1 & KPYM_HUMAN & $\begin{array}{l}\text { Pyruvate kinase isozymes M1/M2 - } \\
\text { Homo sapiens (Human) }\end{array}$ & 58470 & 7.96 & 173 & $15 \%$ & $\uparrow$ & enzyme & Cytosol \\
\hline 2 & TLN1_HUMAN & Talin-1 - Homo sapiens (Human) & 271766 & 5.77 & 44 & $2 \%$ & $\uparrow$ & $\begin{array}{l}\text { cell-cell } \\
\text { junction }\end{array}$ & $\begin{array}{l}\text { Cell membrane; } \\
\text { Cell projection; } \\
\text { Cytoplasm; } \\
\text { Cytoskeleton; } \\
\text { Membrane. }\end{array}$ \\
\hline 3 & LDHB_HUMAN & $\begin{array}{l}\text { L-lactate dehydrogenase B chain - } \\
\text { Homo sapiens (Human) }\end{array}$ & 36900 & 5.71 & 316 & $30 \%$ & $\uparrow$ & enzyme & Cytoplasm. \\
\hline $4,14,15$ & CAP1_HUMAN & $\begin{array}{l}\text { Adenylyl cyclase-associated protein } \\
1 \text { - Homo sapiens (Human) }\end{array}$ & 52222 & 8.27 & 129 & $16 \%$ & $\uparrow$ & $\begin{array}{l}\text { actin } \\
\text { binding }\end{array}$ & $\begin{array}{l}\text { Cell membrane; } \\
\text { PM }\end{array}$ \\
\hline $5,13,16,19$ & ENOA_HUMAN & $\begin{array}{l}\text { Alpha-enolase - Homo sapiens } \\
\text { (Human) }\end{array}$ & 47481 & 7.01 & 217 & $34 \%$ & $\uparrow$ & Enzyme & $\begin{array}{l}\text { Cell membrane; } \\
\text { Cytoplasm; } \\
\text { Membrane; } \\
\text { Nucleus. }\end{array}$ \\
\hline 6 & EHD3_HUMAN & $\begin{array}{l}\text { EH domain-containing protein } 3 \text { - } \\
\text { Homo sapiens (Human) }\end{array}$ & 61971 & 6.06 & 285 & $36 \%$ & $\uparrow$ & $\begin{array}{l}\text { Binding/ } \\
\text { transport }\end{array}$ & $\begin{array}{l}\text { Cell membrane; } \\
\text { Endosome. } \\
\text { Membrane }\end{array}$ \\
\hline 7 & COR1C_HUMAN & $\begin{array}{l}\text { Coronin-1C - Homo sapiens } \\
\text { (Human) }\end{array}$ & 53899 & 6.65 & 253 & $18 \%$ & $\uparrow$ & $\begin{array}{l}\text { Actin- } \\
\text { binding/ } \\
\text { transport }\end{array}$ & actin cytoskeleton \\
\hline 8 & ST1A3_HUMAN & $\begin{array}{l}\text { Sulfotransferase 1A3/1A4 - Homo } \\
\text { sapiens (Human) }\end{array}$ & 34288 & 5.68 & 85 & $23 \%$ & $\uparrow$ & $\begin{array}{l}\text { Actin- } \\
\text { binding/ } \\
\text { transport }\end{array}$ & Cytoplasm \\
\hline 9 & FLNA_HUMAN & Filamin-A - Homo sapiens (Human) & 283301 & 5.7 & 172 & $9 \%$ & $\uparrow$ & $\begin{array}{l}\text { Actin- } \\
\text { binding }\end{array}$ & $\begin{array}{l}\text { Cytoplasm; } \\
\text { Cytoskeleton; } \\
\text { plasma } \\
\text { membrane. }\end{array}$ \\
\hline 10 & VINC_HUMAN & Vinculin - Homo sapiens (Human) & 124292 & 5.5 & 755 & $26 \%$ & $\uparrow$ & $\begin{array}{l}\text { actin } \\
\text { binding }\end{array}$ & $\begin{array}{l}\text { Cytoplasm; } \\
\text { cytoskeleton; } \\
\text { Cell junction; } \\
\text { adherens junction; } \\
\text { Cell membrane; } \\
\text { Peripheral } \\
\text { membrane } \\
\text { protein; }\end{array}$ \\
\hline 11 & IGKC_HUMAN & $\begin{array}{l}\text { Ig kappa chain C region - Homo } \\
\text { sapiens (Human) }\end{array}$ & 11773 & 5.58 & 101 & $80 \%$ & $\uparrow$ & immuno & $\begin{array}{l}\text { extracellular } \\
\text { region }\end{array}$ \\
\hline 12 & GNB1_HUMAN & $\begin{array}{l}\text { Guanine nucleotide-binding protein } \\
\mathrm{G}(\mathrm{I}) / \mathrm{G}(\mathrm{S}) / \mathrm{G}(\mathrm{T}) \text { subunit beta-1 - } \\
\text { Homo sapiens (Human) }\end{array}$ & 38151 & 5.6 & 69 & $31 \%$ & $\downarrow$ & transducer & \\
\hline $17,18,20$ & ACTB_HUMAN & Actin, cytoplasmic 1 & 42052 & 5.29 & 119 & $29 \%$ & $\uparrow$ & $\begin{array}{l}\text { ATP } \\
\text { binding }\end{array}$ & $\begin{array}{l}\text { Cytoplasm; } \\
\text { cytoskeleton. }\end{array}$ \\
\hline
\end{tabular}

${ }^{a}$ Spot no. is the unique number which refers to the labels in Figure 1. Protein spots identified by ESI and MALDI were highlighted by bold and italic.

${ }^{b}$ Accession no. is the MASCOT results of ESI-Ion trap searched from the SWISS-PROT database.

c Molecular weight predicted from database.

d Mascot score was selected identified by HCT.

e Sequence coverage (\%) means the number of amino acids spanned by the assigned peptides divided by the sequence length.

fProtein function from SWISS-PROT database

${ }^{g}$ Protein location from SWISS-PROT database

\section{Western blotting (WB)}

To further confirm the alterations of protein expression between HIV-positive and healthy donors, four proteins-talin-1, filamin A, vinculin and GNB1 were selected for western blotting analysis through pooled and 23 individual samples including 12 from patients and 11 from healthy controls. For vinculin, a fragment with molecular weight of about $80 \mathrm{KDa}$ was over expressed in pooled and almost all the HIV-positive samples (Figure 2B, 2C), which was consistent with that of $2 \mathrm{DE}$. For talin-1, a fragment with $38 \mathrm{KDa}$ was found in pooled samples from HIV-positive patients; 


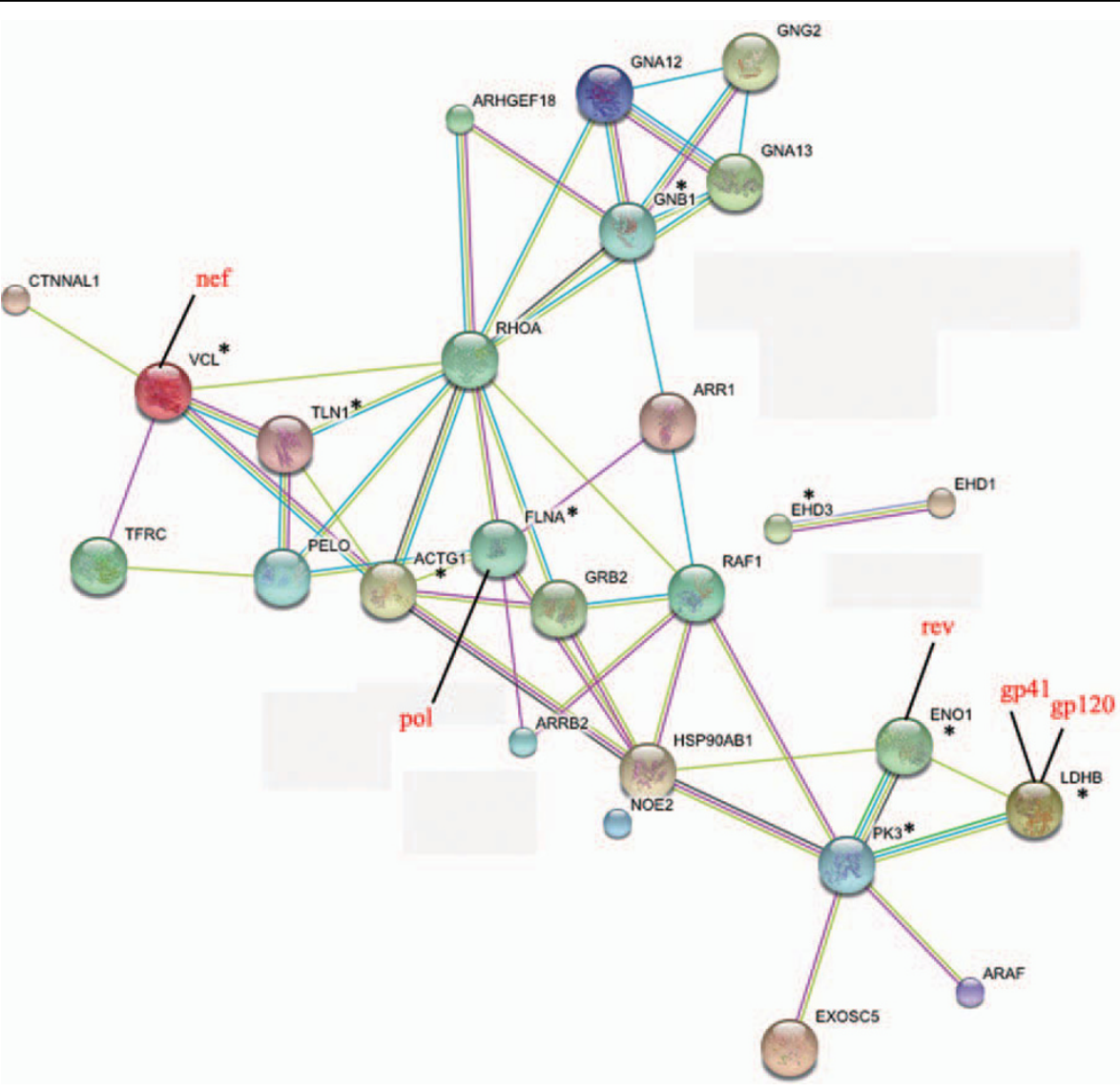

Figure 3 Protein-protein interactions of identified differential proteins with HIV function proteins. Proteins labeled with were differentially expressed proteins identified in our work. Proteins labeled in red character were HIV proteins. The rest proteins were host proteins from the database.

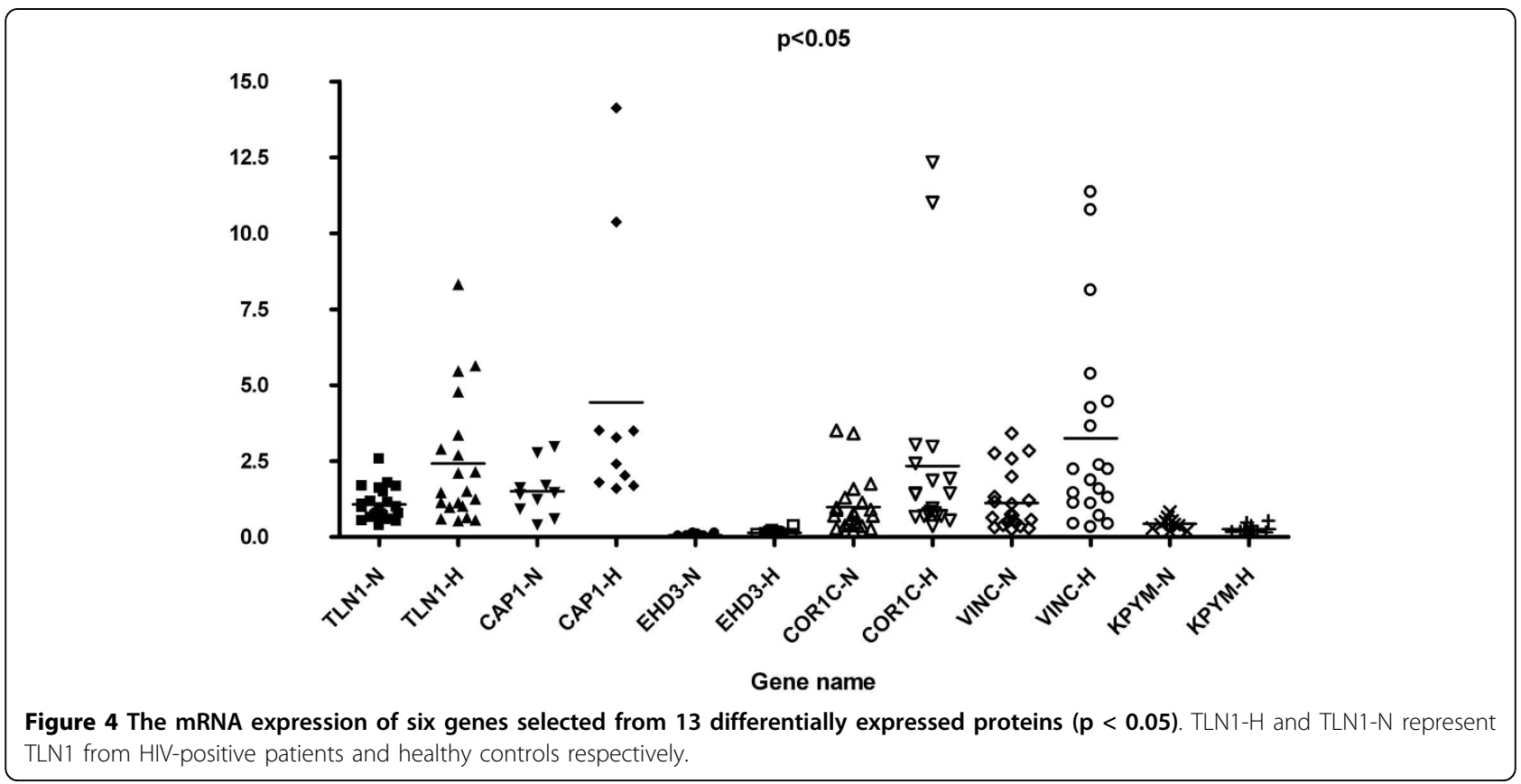


furthermore, this fragment has lower abundance than the other two fragments seen from figure $2 \mathrm{~B}$. Through further WB verification (focusing on this fragment) in the 23 individual samples, we found that this fragment could be detected in $10 \mathrm{HIV}$-positive individuals. However, no positive signal was detected in any healthy controls (figure 2C). For filamin-A, three bands were detected in the samples from healthy donors, while one more band with molecular weight about $70 \mathrm{kDa}$ was found in the pooled and 10 individual samples (Figure 2B, 2C). For GNB1, about 1.8-fold decrease was detected in pooled HIV-1 positive samples. However, GNB1 was found to be down-regulated only in 5 samples of HIVpositive individuals (1, 2, 4, 5 and 11) (Figure 2C). Through statistic analysis, no significant difference $(\mathrm{p}>$ 0.05, data not shown) was detected in HIV-positive patients seeing from our study.

\section{Discussion}

The composition of PBMCs may not be constant due to the contamination from red cells and platelets especially platelets. So, it is important to separate PBMCs according to standard protocol. In this work, we separated the PBMCs according to Ficoll-Paque Plus protocol (recommended by Amersham Pharmacia Biotech), and stored them at $-80^{\circ} \mathrm{C}$ within $4 \mathrm{~h}$ for proteomic research to decrease artificial difference due to sample treatment and storage. Especially, in order to decrease platelet's contamination, four tips were used, including 1) ficoll density gradient centrifugation; 2) softly removing the upper suspension after gradient centrifugation; 3) only absorbing the white PBMCS fraction; 4) PBS wash for twice using low-speed centrifugations (200 g, $10 \mathrm{~min}$ ). Due to the above matters, the platelets were not only decreased for 4 to 12 fold, but also no significant difference was detected in two kinds of samples through Mann-Whitey Test statistic analysis of PBMCS from 12 HIV-positive patients and 9 healthy controls. This indicates that the methods reported in this study are reliable and there is no artificial difference during PBMC separation.

For clinical proteomics, it is one of the main considers to decrease the individual variation. In this work, the sample sizes were at least 9. According to the liver proteomic results reported by He Fuchu et al., the individual variation was not significant when the sample size exceeded 7 [20]. Considering the higher individual variation in HIV-infected patients, and referring the HIVrelated proteomic research [24-26], the sample size used in work was at least 9. So according to our knowledge, the sample size in this work is basically suitable for proteomic research.

Increasing evidence emphasizes comparative proteomics to screen the differentially expressed proteins associated with HIV/AIDS [6,27]. In our study, we obtained a 2DE profile of the altered protein expression of HIV-positive compared with healthy donors. 13 non-redundant differentially expressed proteins were identified by MS/MS. According to their function annotated in SWISS-PROT http://www.expasy.org, these differentially expressed proteins can be classified into four categories (Table 3).

Seven of the differentially expressed proteins have binding function, which were talin-1, filamin-A, vinculin, coronin-1C, EH domain-containing protein 3, adenylyl cyclase-associated protein 1 and actin. Many studies have shown that the level of talin-1 correlates with HIV infection[28,29]. HIV-1-infected effector T cells binding to primary CD4/CXCR4-targeted $\mathrm{T}$ cells results in rapid recruitment to the interface of $\mathrm{CD} 4, \mathrm{CXCR} 4$ and talin [28]. Talin head domain, a fragment of $\mathrm{COOH}$ terminus, was reported to be an immunodominant epitope of the antiplatelet antibody response in patients with HIV-1associated thrombocytopenia[29]. In this study, a new fragment of about $38 \mathrm{kDa}$ was detected. This new fragment might be degraded by HIV [29], or produced during the host cell apoptosis processing for talin involved in cell membrane receptor mediated apoptosis pathway [30] and caspase-mediated cleavage[31]. Vinculin has high affinity to talin-1 [32], and is involved in the attachment of the actin-based microfilaments to the plasma membrane, plays important roles in cell morphology and locomotion [33,34]. Vinculin can be induced to polarizate by HIV-1 Nef [35], were detected to be a caspase- 3 target and over-expressed in apoptotic cells [36]. So the fragment detected in this study might be the degradation product of vinculin and can be used as a marker for cell apoptosis in HIV-positive patients. In this work, we also identify another cytoskeleton protein-filamin A, which can interact with pol (a HIV protein), and was reported to be an adaptor protein that links HIV-1 receptors to the actin cytoskeleton remodelling machinery[37]. Filamin A can be cleaved from 280 $\mathrm{kDa}$ to 170,150 , and $120 \mathrm{kDa}$ major $\mathrm{N}$-terminal fragments, and 135,120 , and $110 \mathrm{kDa}$ major C-terminal fragments when apoptosis was induced[38]. The 280 $\mathrm{kDa}$ representing filamin was decreased in HIV-positive patients [39]. In our research, a fragment with molecular weight of about $70 \mathrm{kDa}$ derived from the $\mathrm{COOH}$ terminus of filamin A was increased. So this fragment might be the product of filamin A cleaved by HIV or proteolyzed during apoptosis for filamin are involved in caspase pathway and can be cleaved in HIV-positive patients. These results are consistent with the present knowledge that HIV induces host cell apoptosis through degrading the proteins related to actin cytoskeletal network.

Four of the proteins were enzymes including L-lactate dehydrogenase B chain, pyruvate kinase isozymes 
M1/M2, adenylyl cyclase-associated protein 1 and sulfotransferase 1A3/1A4. Lactate dehydrogenase B can interact with gp120 and gp41. It was found to be upregulated by HIV-1 gp120/41 [40]. Pyruvate kinase isozymes M1/M2, a glycolytic enzyme that catalyzes the transfer of a phosphoryl group from phosphoenolpyruvate (PEP) to ADP [41], was found to be down-regulated in HIV-1-infected mouse astrocytes[42] and microglia [16]. However, opposite result was found in PBMCs of HIV-positive patients. This result may be due to 1) the difference between in vitro and in vivo protein expression, 2) the difference between PBMCs and astrocytes or microglia. Adenylyl cyclase-associated protein 1 is an metabolism enzyme involved in carbohydrate degradation and glycolysis[43]. Sulfotransferase 1A3/1A4 catalyzes the sulfate conjugation of phenolic monoamines, is an important lipid metabolism enzyme[44]. These upregulated enzymes indicated that a stronger enzyme reaction was induced, and metabolic abnormalities were developed in HIV-infected patients[8,45].

In this work, we also identified three signal transduction proteins. They were GNB1, EH domain-containing protein 3 and coronin-1C. Of which, GNB1 was selected for further verification for it involved as a modulator or transducer in various transmembrane signaling systems [46]. According to the description by Nancy Vazquez [47], the gene expression of GNB1 was found to be upregulated by 5.0 -fold in macrophages infected by HIV-1 compared with uninfected cells. Similarly, Sharon M. Wahl [48] reported that HIV not only induced the upregulation of GNB1, but the up-regulation of GNB1 could facilitate HIV-1 replication in macrophages. However, we detected this protein was down-regulated in HIV-positive patients analyzed from pooled and part of individual samples. Maybe it is due to the following reasons: 1) Vazquez [47] and Wahl [48] analyzed GNB1 from gene level. However, there are only $50 \%$ consistent between mRNA level and protein level. 2) Vazquez [47] and Wahl [48] analyzed GNB1 in vitro (HIV-infected macrophages). However, we studied it in vivo. Maybe it is due to the difference between in vitro and in vivo. 3) Vazquez [47] and Wahl [48] reported the up-regulation of GNB1 in macrophages infected by HIV, while we detected the down-regulated in PBMCs including other mononuclear cells as well as macrophages. Further, we only detected the down-regulated expression of GNB1 in part of samples, so there must be some other factors affecting the expression of GNB1. Further researches are needed, such as studying the expression of this protein in different cell groups. We also found one protein- Ig kappa chain $C$ region related to immune response[49].

According to bio-informatics, these proteins interact with each other as shown in Figure 3. HIV infection affects a wide protein network, some of which were observed before and many were discovered for the first time in this work as discussed above.

It is interesting that most of the identified differential proteins were membrane or membrane-related proteins with binding function although we did not enrich membrane. The up-regulated membrane protein fragment further verified the idea that HIV destructed host cells through degrading the cytokeratin proteins such as talin, filamin A and vinculin[29,50].

\section{Conclusions}

In conclusion, this study adopted a gel-based proteomic approach to probe changed proteins in PBMCs of HIVpositive patients. It is noteworthy that the comparative proteomic approach allowed for the initial identification of 13 altered cellular proteins in HIV-positive patients compared with healthy donors and showed most of the altered cellular proteins are involved in enzyme activation, cell-connection and signaling transduction. A wide protein-protein interaction network was affected in HIV-positive patients. Our study can offer some help in revealing the interactions between HIV and host cell.

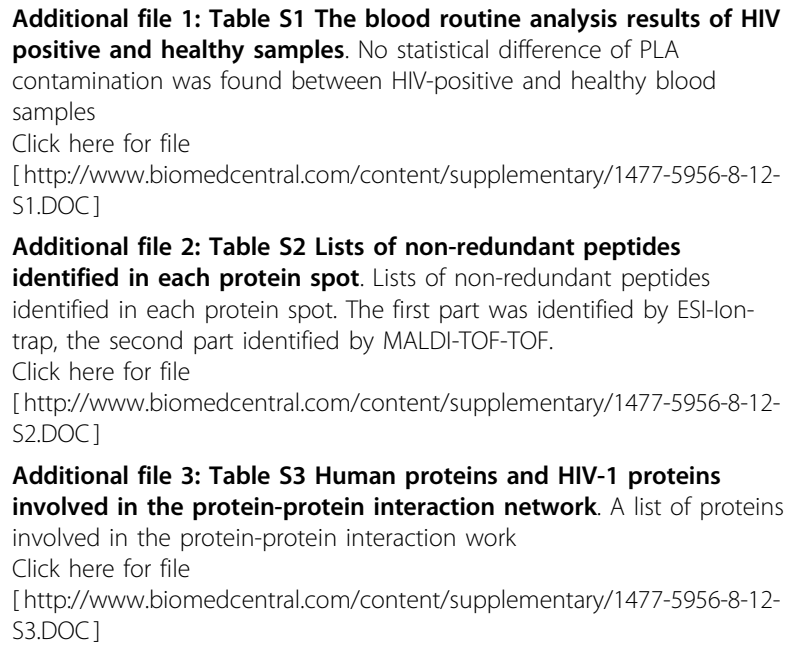

Additional file 2: Table S2 Lists of non-redundant peptides identified in each protein spot. Lists of non-redundant peptides identified in each protein spot. The first part was identified by ESI-lontrap, the second part identified by MALDI-TOF-TOF.

Click here for file

[ http://www.biomedcentral.com/content/supplementary/1477-5956-8-12S2.DOC ]

Additional file 3: Table S3 Human proteins and HIV-1 proteins involved in the protein-protein interaction network. A list of proteins involved in the protein-protein interaction work

Click here for file

[http://www.biomedcentral.com/content/supplementary/1477-5956-8-12S3.DOC ]

\section{Abbreviations}

HIV: human immunodeficiency virus; PBMCs: peripheral blood mononuclear cells; AIDS: acquired immune deficiency syndrome; HAART: high activity antiretroviral therapy; GAPDH: glyceraldehyde-3-phosphate dehydrogenase; HCT: high capacity trap.

\section{Acknowledgements}

This work was supported by "Research Foundation for Talented Scholars by Shanghai Public Clinical Center (RCJJP2)", "Basic research supported by the Ministry of Health (WA-2007-04)", and "National Key Technology R\&D

Program of China (Grant No. 2008ZX10001-008)". We thank Prof. Jianqing Xu (Fudan University, China) for reviewing this manuscript.

\section{Author details}

'Shanghai Public Health Clinical Center affiliated to Fudan University,

Shanghai, 201508, PR China. ${ }^{2}$ Neurosurgery, Fuzhou General Hospital, Fuzhou 
350025, PR China. ${ }^{3}$ Institutes of Biomedical Sciences, Fudan University, Shanghai, 200032, PR China.

\section{Authors' contributions}

LZ designed the study, participated in statistical analysis of experiment data, interpret the experiment data and draft the manuscript. XJ carried out protein identification. $X Z$, JS and TQ carried out clinical blood sample collection. XP and CQ carried out PBMCs isolation and 2DE. FM carried out real time RT-PCR and data analysis. $L Y$ and $Y Y$ participated in western blot. $\mathrm{HL}$ revised the manuscript critically. All authors read and approved the final manuscript.

\section{Competing interests}

The authors declare that they have no competing interests.

Received: 24 November 2009 Accepted: 12 March 2010 Published: 12 March 2010

\section{References}

1. O'Brien ME, Clark RA, Besch CL, Myers L, Kissinger P: Patterns and correlates of discontinuation of the initial HAART regimen in an urban outpatient cohort. J Acquir Immune Defic Syndr 2003, 34:407-414.

2. Fellay J, Boubaker K, Ledergerber B, Bernasconi E, Furrer H, Battegay M, Hirschel B, Vernazza P, Francioli P, Greub G, Flepp M, Telenti A: Prevalence of adverse events associated with potent antiretroviral treatment: Swiss HIV Cohort Study. Lancet 2001, 358:1322-1327.

3. Wollscheid B, Watts JD, Aebersold R: Proteomics/genomics and signaling in lymphocytes. Curr Opin Immunol 2004, 16:337-344.

4. Spetz AL, Patterson BK, Lore K, Andersson J, Holmgren L: Functional gene transfer of HIV DNA by an HIV receptor-independent mechanism. $J$ Immunol 1999, 163:736-742.

5. Chen Z, Cheng Y, Xu Y, Liao J, Zhang X, Hu Y, Zhang Q, Wang J, Zhang Z, Shen $F$, Yuan $Z$ : Expression profiles and function of Toll-like receptors 2 and 4 in peripheral blood mononuclear cells of chronic hepatitis $B$ patients. Clin Immunol 2008, 128:400-408.

6. List EO, Berryman DE, Bower B, Sackmann-Sala L, Gosney E, Ding J, Okada S, Kopchick JJ: The use of proteomics to study infectious diseases. Infect Disord Drug Targets 2008, 8:31-45.

7. D'Andrea G, Brisdelli F, Bozzi A: AZT: an old drug with new perspectives. Curr Clin Pharmacol 2008, 3:20-37.

8. Rasheed S, Yan JS, Lau A, Chan AS: HIV replication enhances production of free fatty acids, low density lipoproteins and many key proteins involved in lipid metabolism: a proteomics study. PLOS ONE 2008, 3: e3003.

9. Ciborowski P, Enose Y, Mack A, Fladseth M, Gendelman HE: Diminished matrix metalloproteinase 9 secretion in human immunodeficiency virusinfected mononuclear phagocytes: modulation of innate immunity and implications for neurological disease. J Neuroimmunol 2004, 157:11-16.

10. Barrett L, Gallant M, Howley C, Bowmer MI, Hirsch G, Peltekian K, Grant M: Enhanced IL-10 production in response to hepatitis $C$ virus proteins by peripheral blood mononuclear cells from human immunodeficiency virus-monoinfected individuals. BMC Immunol 2008, 9:28.

11. Calarota SA, Foli A, Maserati R, Baldanti F, Paolucci S, Young MA, Tsoukas CM, Lisziewicz J, Lori F: HIV-1-specific T cell precursors with high proliferative capacity correlate with low viremia and high CD4 counts in untreated individuals. J Immunol 2008, 180:5907-5915.

12. Minga AK, Anglaret $X, d^{\prime}$ Aquin Toni $T$, Chaix ML, Dohoun $L, A b o Y$, Coulibaly A, Duvignac J, Gabillard D, Rouet F, Rouzioux C: HIV-1 DNA in peripheral blood mononuclear cells is strongly associated with HIV-1 disease progression in recently infected West African adults. J Acquir Immune Defic Syndr 2008, 48:350-354.

13. Sternfeld T, Tischleder A, Schuster M, Bogner JR: Mitochondrial membrane potential and apoptosis of blood mononuclear cells in untreated HIV-1 infected patients. HIV Med 2009, 10:512-519.

14. Gougeon ML, Lecoeur H, Dulioust A, Enouf MG, Crouvoiser M, Goujard C, Debord T, Montagnier L: Programmed cell death in peripheral lymphocytes from HIV-infected persons: increased susceptibility to apoptosis of CD4 and CD8 T cells correlates with lymphocyte activation and with disease progression. J Immunol 1996, 156:3509-3520.

15. Franceschi C, Franceschini MG, Boschini A, Trenti T, Nuzzo C, Castellani G, Smacchia C, De Rienzo B, Roncaglia R, Portolani M, Pietrosemoli P,
Meacci M, Pecorari M, Sabbatini A, Malorni W, Cossarizza A: Phenotypic characteristics and tendency to apoptosis of peripheral blood mononuclear cells from HIV+ long term non progressors. Cell Death Differ 1997, 4:815-823.

16. Wang T, Gong N, Liu J, Kadiu I, Kraft-Terry SD, Mosley RL, Volsky DJ, Ciborowski P, Gendelman HE: Proteomic modeling for HIV-1 infected microglia-astrocyte crosstalk. PLOS ONE 2008, 3:e2507.

17. He F, Zeng $Y$, Wu X, Ji Y, He X, Andrus T, Zhu T, Wang T: Endogenous HIV1 Vpr-mediated apoptosis and proteome alteration of human T-cell leukemia virus-1 transformed C8166 cells. Apoptosis 2009, 14:1212-1226.

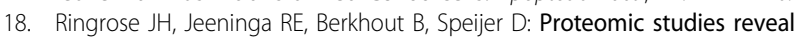
coordinated changes in T-cell expression patterns upon infection with human immunodeficiency virus type 1. J Virol 2008, 82:4320-4330.

19. Xiaobo $H$, Yong L, Daming J, Lei $X$, Ying S, Jinfeng Z: External quality assessment of automated hematology analyzer performance using fresh human blood samples in Shanghai. Lab Hematol 2003, 9:175-178.

20. Zhang L, Liu X, Zhang J, Cao R, Lin Y, Xie J, Chen P, Sun Y, Li D, Liang S: Proteome analysis of combined effects of androgen and estrogen on the mouse mammary gland. Proteomics 2006, 6:487-497.

21. Gorg A, Postel W, Domscheit A, Gunther S: Two-dimensional electrophoresis with immobilized $\mathrm{pH}$ gradients of leaf proteins from barley (Hordeum vulgare): method, reproducibility and genetic aspects. Electrophoresis 1988, 9:681-692.

22. Zhang L, Xie J, Wang X, Liu X, Tang X, Cao R, Hu W, Nie S, Fan C, Liang S: Proteomic analysis of mouse liver plasma membrane: use of differential extraction to enrich hydrophobic membrane proteins. Proteomics 2005, 5:4510-4524

23. Zhang L, Wang X, Peng X, Wei Y, Cao R, Liu Z, Xiong J, Ying X, Chen P, Liang S: Immunoaffinity purification of plasma membrane with secondary antibody superparamagnetic beads for proteomic analysis. $J$ Proteome Res 2007, 6:34-43.

24. Wiederin J, Rozek W, Duan F, Ciborowski P: Biomarkers of HIV-1 associated dementia: proteomic investigation of sera. Proteome Sci 2009, 7:8.

25. Pendyala G, Trauger SA, Kalisiak E, Ellis RJ, Siuzdak G, Fox HS: Cerebrospinal fluid proteomics reveals potential pathogenic changes in the brains of SIV-infected monkeys. J Proteome Res 2009, 8:2253-2260.

26. Laspiur JP, Anderson ER, Ciborowski P, Wojna V, Rozek W, Duan F, Mayo R, Rodriguez E, Plaud-Valentin M, Rodriguez-Orengo J, Gendelman HE, Melendez LM: CSF proteomic fingerprints for HIV-associated cognitive impairment. J Neuroimmunol 2007, 192:157-170.

27. Luciano-Montalvo C, Ciborowski P, Duan F, Gendelman HE, Melendez LM: Proteomic Analyses Associate Cystatin B with Restricted HIV-1 Replication in Placental Macrophages. Placenta 2008, 29:1016-1023.

28. Jolly C, Kashefi K, Hollinshead M, Sattentau QJ: HIV-1 cell to cell transfer across an Env-induced, actin-dependent synapse. J Exp Med 2004 199:283-293.

29. Koefoed $\mathrm{K}$, Ditzel HJ: Identification of talin head domain as an immunodominant epitope of the antiplatelet antibody response in patients with HIV-1-associated thrombocytopenia. Blood 2004, 104:4054-4062.

30. Foger N, Rangell L, Danilenko DM, Chan AC: Requirement for coronin 1 in T lymphocyte trafficking and cellular homeostasis. Science 2006 313:839-842.

31. Lesay A, Hickman JA, Gibson RM: Disruption of focal adhesions mediates detachment during neuronal apoptosis. Neuroreport 2001, 12:2111-2115.

32. Izard T, Vonrhein C: Structural basis for amplifying vinculin activation by talin. J Biol Chem 2004, 279:27667-27678.

33. Izard $T$, Evans $G$, Borgon RA, Rush CL, Bricogne G, Bois PR: Vinculin activation by talin through helical bundle conversion. Nature 2004, 427:171-175.

34. Nhieu GT, lzard T: Vinculin binding in its closed conformation by a helix addition mechanism. Embo J 2007, 26:4588-4596.

35. Quaranta MG, Mattioli B, Spadaro F, Straface E, Giordani L, Ramoni C, Malorni W, Viora M: HIV-1 Nef triggers Vav-mediated signaling pathway leading to functional and morphological differentiation of dendritic cells. Faseb J 2003, 17:2025-2036.

36. Propato A, Cutrona G, Francavilla V, Ulivi M, Schiaffella E, Landt O, Dunbar R, Cerundolo V, Ferrarini $M$, Barnaba V: Apoptotic cells overexpress vinculin and induce vinculin-specific cytotoxic T-cell cross-priming. Nat Med 2001, 7:807-813 
37. Jimenez-Baranda S, Gomez-Mouton C, Rojas A, Martinez-Prats L, Mira E, Ana Lacalle R, Valencia A, Dimitrov DS, Viola A, Delgado R, Martinez AC, Manes S: Filamin-A regulates actin-dependent clustering of HIV receptors. Nat Cell Biol 2007, 9:838-846.

38. Umeda T, Kouchi Z, Kawahara H, Tomioka S, Sasagawa N, Maeda T, Sorimachi H, Ishiura S, Suzuki K: Limited proteolysis of filamin is catalyzed by caspase-3 in U937 and Jurkat cells. J Biochem 2001, 130:535-542.

39. Tandon R, Levental I, Huang C, Byfield FJ, Ziembicki J, Schelling JR, Bruggeman LA, Sedor JR, Janmey PA, Miller RT: HIV infection changes glomerular podocyte cytoskeletal composition and results in distinct cellular mechanical properties. Am J Physiol Renal Physiol 2007, 292: F701-710.

40. Boutet A, Altmeyer R, Hery C, Tardieu M: Direct role of plasma membraneexpressed gp120/41 in toxicity to human astrocytes induced by HIV-1infected macrophages. Aids 2000, 14:2687-2697.

41. Olsen JV, Blagoev B, Gnad F, Macek B, Kumar C, Mortensen P, Mann M: Global, in vivo, and site-specific phosphorylation dynamics in signaling networks. Cell 2006, 127:635-648.

42. Wang T, Gong N, Liu J, Kadiu I, Kraft-Terry SD, Schlautman JD, Ciborowski P, Volsky DJ, Gendelman HE: HIV-1-infected astrocytes and the microglial proteome. J Neuroimmune Pharmacol 2008, 3:173-186.

43. Gupta N, Shankernarayan NP, Dharmalingam K: Serum proteome of leprosy patients undergoing erythema nodosum leprosum reaction: regulation of expression of the isoforms of haptoglobin. J Proteome Res 2007, 6:3669-3679.

44. Wood TC, Aksoy IA, Aksoy S, Weinshilboum RM: Human liver thermolabile phenol sulfotransferase: CDNA cloning, expression and characterization. Biochem Biophys Res Commun 1994, 198:1119-1127.

45. Lorenz MW, Stephan C, Harmjanz A, Staszewski S, Buehler A, Bickel M, von Kegler S, Ruhkamp D, Steinmetz H, Sitzer M: Both long-term HIV infection and highly active antiretroviral therapy are independent risk factors for early carotid atherosclerosis. Atherosclerosis 2008, 196:720-726.

46. Niu J, Profirovic J, Pan H, Vaiskunaite R, Voyno-Yasenetskaya T: G Protein betagamma subunits stimulate p114RhoGEF, a guanine nucleotide exchange factor for RhoA and Rac1: regulation of cell shape and reactive oxygen species production. Circ Res 2003, 93:848-856.

47. Vazquez N, Greenwell-Wild T, Marinos NJ, Swaim WD, Nares S, Ott DE, Schubert U, Henklein P, Orenstein JM, Sporn MB, Wahl SM: Human immunodeficiency virus type 1-induced macrophage gene expression includes the p21 gene, a target for viral regulation. J Virol 2005, 79:4479-4491.

48. Wahl SM, Greenwell-Wild T, Peng G, Ma G, Orenstein JM, Vazquez N: Viral and host cofactors facilitate HIV-1 replication in macrophages. I Leukoc Biol 2003, 74:726-735.

49. Olsen KE, Sletten K, Westermark P: Extended analysis of AL-amyloid protein from abdominal wall subcutaneous fat biopsy: kappa IV immunoglobulin light chain. Biochem Biophys Res Commun 1998, 245:713-716.

50. Shoeman RL, Hartig R, Hauses C, Traub P: Organization of focal adhesion plaques is disrupted by action of the HIV-1 protease. Cell Biol Int 2002, 26:529-539.

doi:10.1186/1477-5956-8-12

Cite this article as: Zhang et al:: Proteomic analysis of PBMCs:

characterization of potential HIV-associated proteins. Proteome Science 2010 8:12.

\section{Submit your next manuscript to BioMed Central and take full advantage of:}

- Convenient online submission

- Thorough peer review

- No space constraints or color figure charges

- Immediate publication on acceptance

- Inclusion in PubMed, CAS, Scopus and Google Scholar

- Research which is freely available for redistribution

Submit your manuscript at www.biomedcentral.com/submit 